\title{
Health of Laying Hens in an Aviary System over Five Batches of Birds
}

\author{
By P. Abrahamsson ${ }^{1}$, O. Fossum ${ }^{2}$ and R. Tauson ${ }^{1}$ \\ ${ }^{1}$ Swedish University of Agricultural Sciences and ${ }^{2}$ Swedish Veterinary Institute, Uppsala, Sweden.
}

\begin{abstract}
Abrahamsson P, Fossum O, Tauson R: Health of laying hens in an aviary system over five batches of birds. Acta vet. scand. 1998, 39, 367-379. - Mortality and health were studied in laying hens kept in an aviary system on a practical scale. All management inputs were done by university staff. Five batches of birds (trials) during a period of 6 years with approximately 4700 birds per trial were included in the study. The aviary was a three-tiered "Marielund" system divided into 4 pens. Three hybrids, reared on litter with access to perches, were used; Lohmann Selected Leghorn (LSL), Lohmann Brown (LB) and an experimental cross (SLU-1329). The hens were not beak-trimmed. The stocking density was 17 hens $/ \mathrm{m}^{2}$ ground floor. Mortality varied between pens and between batches, ranging from normal rates of $3.4 \%$ to $7.8 \%$, except in LSL in Trial 2 and LB in Trial 3 where it was much higher ( $15.6 \%$ and $20.9 \%$, respectively). The dominating causes of total mortality were salpingitis and cannibalism. Coccidiosis and lymphoid leucosis contributed significantly to mortality in Trial 2 . An infestation with fowl mites (Dermanyssus gallinae) occurred in Trial 1. Feather loss was most severe in LB. Keel bone deviations were recorded at increasing levels by age. Foot abscesses occurred more frequently at 35 weeks than at 55 weeks. LSL was more severely affected than LB and SLU-1329.
\end{abstract}

housing system; coccidiosis; mites; salpingitis; serology; bumble foot; keel bone; feather pecking; cannibalism.

\section{Introduction}

During recent years, concern has been raised both by the public and by scientists about the impact of battery cage housing on welfare of laying hens. A high incidence of foot damage, feather loss and brittle bones has been observed in layers housed in battery cages (Tauson 1980, Svedberg 1988, Gregory \& Wilkins 1989, Appleby 1993). Moreover, conventional cages restrict the movements of hens and prevent certain important behaviours, such as laying eggs in nests, scratching and bathing in sand or soil, and roosting on a perch (Hansen 1993, Abrahamsson et al. 1996a). It has been suggested that aviaries may be a commercial alternative to

cages providing a larger total available area for the hens and access to nests, litter and perches (Blokhuis \& Metz 1992, Taylor \& Hurnik 1994, Abrahamsson \& Tauson 1995, Kathle \& Kolstad 1996). Since most aviaries are furnished with tiers of wire floor on several levels, the number of hens per $\mathrm{m}^{2}$ floor can still be kept on a level similar to that in cages, and therefore the buildings will be more effectively used, e.g. from an energy heat-saving point of view, than traditional low stocking density systems. However, more problems with feather pecking and cannibalism may occur in large flocks of non beak-trimmed birds (Keeling 1994) and birds 
kept at high stocking density (Simonsen et al. 1980). Moreover, problems with parasites may be greater when the hens have access to litter. In a comprehensive investigation from field data obtained in commercial scale large aviary farms using beak-trimmed birds in the Netherlands, Blokhuis \& Metz (1996) and van Horne (1997) reported similar production and mortality results as in cages. However, medical treatments against parasitic disorders resulted in higher costs for aviary eggs. Similar results from smaller flocks but with an increase in mortality and decrease in production, and less predictability of production, was reported from Switzerland by Meierhans et al. (1992).

The aim of the present investigation was to study health and mortality of laying hens in an aviary system on a practical scale during 5 trials (between March 1988 and June 1995), under Swedish conditions. In Sweden, beak-trimming is prohibited. The winter temperatures may be very low for long periods and the stocking density of birds is restricted compared with most countries on the European continent. Rearing farms are often situated far from the egg-laying farm.

\section{Materials and methods}

The study was carried out at Marielund farm, Uppsala, located $9 \mathrm{~km}$ from the Funbo-Lövsta Research Centre, and $22 \mathrm{~km}$ from the National Veterinary Institute. The management and collection of crude data were carried out and the project administrated by the Dept. of Animal Nutrition and Management at the Swedish University of Agricultural Sciences (SLU) in Uppsala. The first 2 batches of birds were partly reported by Tauson et al. (1992).

\section{The aviary system}

A room inside a barn was used, measuring $53.0 \mathrm{~m} \times 5.6 \mathrm{~m}$ and $3.1 \mathrm{~m}$ high. In this room, an aviary system was installed, measuring $\mathbf{4 8 . 2}$ $\mathrm{m} \times 5.6 \mathrm{~m}$. The aviary system, Marielund, is a modified Swiss system, consisting of 3 tiers and an aisle of litter floor (Fig. 1). The 2 lower tiers have feeders and the top resting tier has perches. All 3 tiers are equipped with water nipples. In the present building, the litter floor area comprised about $20 \%$ of the total available area. The room was divided by wire netting walls into 4 pens of equal size.

Throughout the trials, attempts were made to improve details of aviary design. In Trial 1 the perches on the top resting tier were made of oak. There were also softwood perches on the covers over the egg collection belts, but these were removed in Trial 2. In Trial 2 the perches on the resting tier in 2 of the pens were oak perches of a rectangular design installed across instead of along the upper tier. In this trial, spillage cups were installed under the water nipples in the aviary. In Trial 3 all perches on the resting tier were made of European beech hardwood, round with a flattened upper surface (Tauson \& Abrahamsson 1994). In Trials 4 and 5 , the perches in one pen were lined with rubber (Tauson \& Abrahamsson 1996).

Nests in 3 tiers were attached to the walls of the room opposite the aviary tiers. In Trial 1 a plastic bowl nest design with perforated bottom (Facco ${ }^{\circledR}, 35010$ Marsango, Italy) was used. From Trial 2 and onwards, 2 designs of nests were used, i.e. the plastic bowl and a nest lined with an artificial turf bottom. In Trial 3, the artificial turf was replaced by turf with small holes. In order to reduce soiling of nests in 2 of the pens (Facco-nests only), they were equipped with a time monitored one-way closing/folding and sloping metal plate which prevented birds from entering the nests $30 \mathrm{~min}$ before dark until $30 \mathrm{~min}$ before light. When folded forwards, the plate also caused old litter, accumulated during the day under the perforated nest bottom, to slide and fall out into the litter bed. The metal plate also served to prevent light coming 


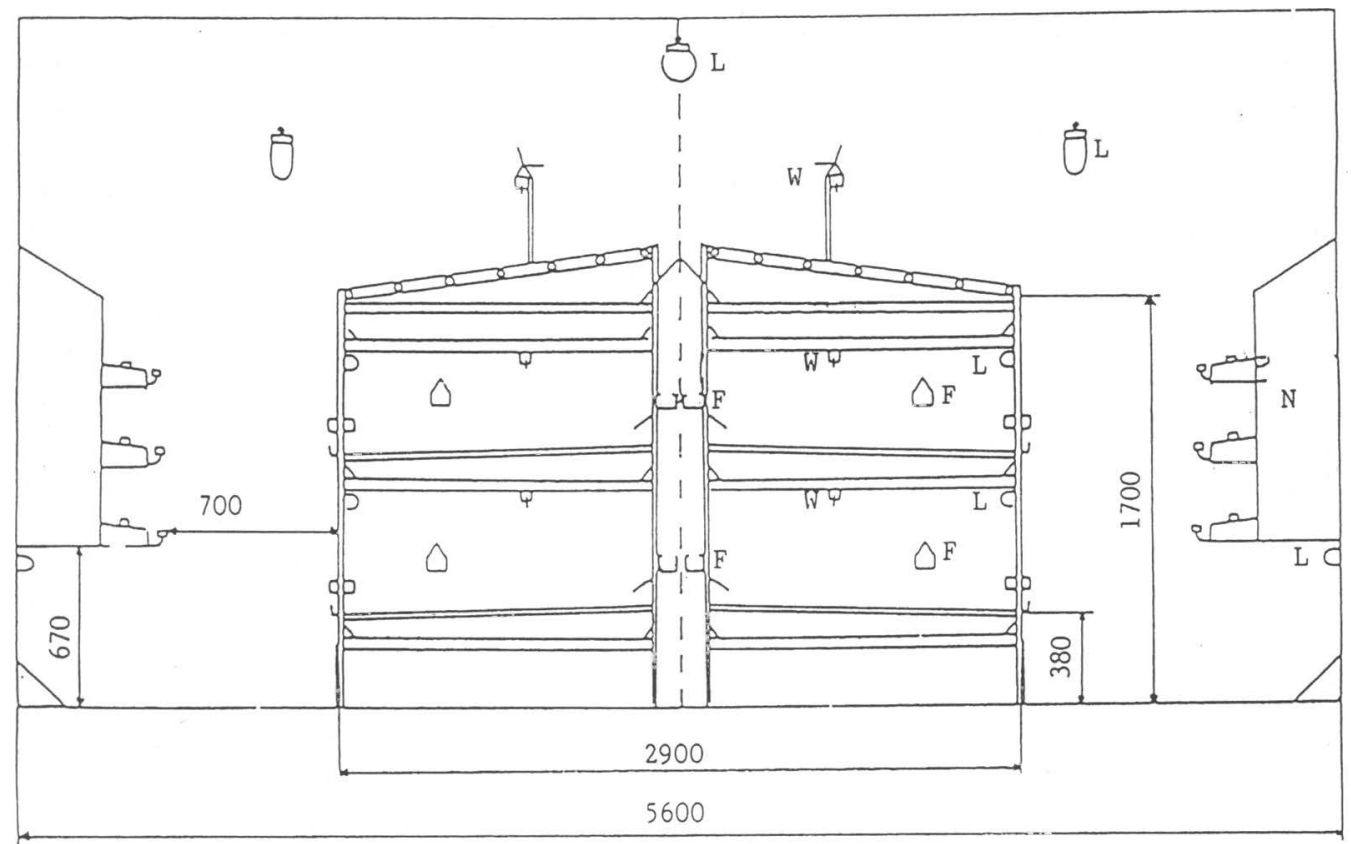

Figure 1. Section of the aviary house. $\mathrm{W}=$ water nipples, $\mathrm{F}=$ feed trough, $\mathrm{N}=$ nests.

in from below through the perforated nest bottom in order to minimise disturbance to hens entering the nests.

The system has belts for manure removal under each wire tier floor, and automatic flat chain feeders. Egg collection belts were used outside the nests and egg collection was done once a day. Misplaced eggs were collected 5 times a day until the number of such eggs had declined to an acceptable level, and thereafter a maximum of 3 times a day. Manure removal belts were run twice a week. The litter was kept in acceptable condition by adding some fresh wood shavings when necessary. Removal of litter was not necessary and hence, seldom carried out except in connection with outbreaks of coccidiosis.

\section{Rearing lighting and feeding}

The pullets were reared on farms $650 \mathrm{~km}$ from the laying house in Trials 1 and 2, 500 $\mathrm{km}$ in Trial 3, and $350 \mathrm{~km}$ from the laying house in Trials 4 and 5. In Trial 1, the pullets were reared on litter with perches at 30,60 and $90 \mathrm{~cm}$ above the floor and with feed and water on the floor. In Trials 2 and 3 the pullets were reared in cages until they were 4 weeks of age and thereafter on litter floor with manure bins covered with netting and with perches on top. Feeders and drinkers were located on the netting. In Trial 4 the pullets were reared in cages until 4 weeks, and thereafter on floor with manure bins covered with netting, and with feed and water on the netting. In Trial 5, the pullets were reared on floor during the first weeks, and thereafter on floor with manure bins as in Trial 4. The birds were not beak-trimmed.

At 16 weeks of age the pullets were transferred to the laying house. The numbers of birds housed per flock were slightly different and 
partly dependent on bird live weight. In Trial 1 a total of 4632 pullets, Lohmann Selected Leghorn (LSL), were used, 1158 per pen. This implied 17 hens per $\mathrm{m}^{2}$ ground floor, 9.2-9.3 hens per $\mathrm{m}^{2}$ of available area and slightly more than 4 hens per nest. In Trial 2, a total of 4700 LSL-pullets were housed, 1175 in each pen. In Trial 3, in 2 pens 1208 with LSL-hens per pen were used. In the other 2 pens, 1033 and 1034 Lohmann Brown were housed. In this trial at 20 weeks the number of hens was reduced to 2 pens with 1175 LSL-hens per pen and the other 2 with 1000 Lohmann Brown. In Trial 4, a total of 4799 LSL-hens were housed and at 20 weeks the number of hens was reduced to 1175 hens per pen. Trial 5 had 2 pens of 1200 and 1199 LSL-hens per pen. In the other 2, 1210 and 1211 hens per pen were housed. They were of a Rhode Island Red $\times$ White Leghorn hybrid (SLU-1329), an experimental cross developed at the Department of Animal Breeding and Genetics, Swedish University of Agricultural Sciences.

At 16 weeks the pullets were given $8 \mathrm{~h}$ of light per day. Light was successively increased to 16 $\mathrm{h}$ per day at 30 weeks. In Trial 1 an artificial dawn and dusk of $16 \mathrm{~min}$ were used. In Trials 2 to 5 , the light was turned on/off according to a special procedure in order to prepare birds for certain activities during periods of light and dark (Tanaka \& Hurnik 1991), e.g. to facilitate the finding of food and water and to calmly find their way up to the perches on the resting top tier. Hence, in the morning, the light was first turned on instantly in the feeding tiers and over the litter area and then, 15 min later, the light over the top resting tier was successively increased during $15 \mathrm{~min}$. In the evening, the procedure was reversed, i.e. the light was turned off first in the feeding tiers and over the litter and then the light over the top tier was dimmed. Until 18 weeks the pullets were fed a grower's mash containing $15.0 \%$ crude protein (CP),
10.9 MJ metabolizable energy (ME) per $\mathrm{kg}, 1 \%$ $\mathrm{Ca}$ and $0.7 \%$ P. During the following production period until slaughter at 80 weeks, the hens were fed a commercial type of layer's mash meal containing $15.0 \% \mathrm{CP}, 11.5 \mathrm{MJ} \mathrm{ME}$ per $\mathrm{kg}$, $3.5 \% \mathrm{Ca}$ and $0.6 \%$ P. Chicks reared for trials 1 , 2 and 3 were treated prophylactically with anticoccidials. Starter feed contained $125 \mathrm{ppm}$ amprolium and $8 \mathrm{ppm}$ ethopabate and grower feed 75 ppm and 5 ppm, respectively. No anticoccidials were given to birds of trials 4 and 5 during rearing, but the grower feed in all 5 trials at housing at 16 weeks contained $75 \mathrm{ppm}$ amprolium.

\section{Recording and statistical analysis of data}

All birds were vaccinated against Marek's disease and avian encephalomyelitis. Serological examinations were performed at about 16 weeks of age and at the end of the production period. From each flock, 20 blood samples were tested for antibodies against infectious bronchitis virus (IBV), Newcastle disease virus (NDV), infectious bursal disease virus (IBDV) and Mycoplasma gallisepticum (MG).

Mortality was recorded from 16 until 20 weeks, and from 20 weeks until 80 weeks, respectively. All dead birds were autopsied. At 35 and 55 weeks, live weights, plumage condition, keel bone lesions, foot health and occurrence of wounds, pecks and scratches were recorded on randomly selected birds. In Trial 1, 15 hens per pen were scored, in Trial 2 at 35 weeks and at 55 weeks 30 and 15 hens per pen were scored, respectively, and in Trial 3, 30 hens per pen were scored. In Trial 4 , in the pen with rubber perches, 60 hens and in the other 3 pens 20 hens per pen were scored. In Trial 5, 40 hens per pen were scored. The scoring was performed according to Tauson et al. (1984), implying a score from 1 to 4 points where 4 means no damage and 1 a very poor condition. Regarding bumble foot, 1 indicates a well-developed foot 
abscess and 3 minor damage or crust formation on the foot pad. The plumage condition was recorded separately on the neck, breast, back, wings and tail and cloaca/abdomen region. However, in Trial 1 and at 35 weeks in Trial 2, plumage at the cloaca/abdomen and rear wounds were not scored separately.

Production and egg quality were registered during the experiment (Abrahamsson \& Tauson 1998).

Statistical analyses were performed using the General Linear Models of the statistical analysis system SAS (SAS Institute Inc. 1989). The pens were used as replicates, and hybrid was considered a fixed effect. Before analysis, mortality was subjected to arcsin transformation (Snedecor \& Cochran 1968).

\section{Results}

Mortality

Mortality varied considerably between trials and between hybrids (Tables 1 and 2). In trials 2 and 3 mortality was exceptionally high while in trials 1,4 and 5, mortality figures were close to the average value of caged layers in Sweden. In trials 3 and 5, LB and SLU-1329 showed a significantly higher mortality than LSL $(p<0.05)$. Salpingitis and cloacal cannibalism were the most important causes of mortality during the 5 trials. In Trial 2, however, also coccidiosis and lymphoid leucosis contributed significantly to the high mortality. In the first trial, $1.5 \%$ of the birds died because of emaciation during the first 4 weeks after transfer to the layer house (16-20 weeks). In the following trials this problem decreased significantly. Coccidiosis was a significant cause of the high mortality in Trial 2 and was even observed as a cause of a few deaths in Trial 3. In both cases, the disease occurred at the start of laying. In the first case, treatment with sulphaclosin combined with removal of litter and addition of
Table 1 . Mortality in the different pens from 20 until 80 weeks. $a=$ LB; $b=$ SLU-1329; all others = LSL.

\begin{tabular}{lrrcc}
\hline Trial & \multicolumn{4}{c}{ Mortality } \\
\hline 1 & 3.7 & 3.7 & 5.1 & 3.6 \\
2 & 11.4 & 16.4 & 18.2 & 16.5 \\
3 & 6.8 & 5.7 & $23.7^{\mathrm{a}}$ & $18.1^{\mathrm{a}}$ \\
4 & 7.8 & 7.0 & 5.6 & 3.4 \\
5 & 5.9 & 6.1 & $7.4^{\mathrm{b}}$ & $7.0^{\mathrm{b}}$ \\
\hline
\end{tabular}

fresh litter material was carried out. Due to Swedish restrictions on withdrawal times of eggs at medication with this compound, eggs were discarded for one week. In the second case, the only action taken was a change of litter material. During rearing of the chicks destined for trial 5, clinical coccidiosis was observed at 4 weeks of age, with a mortality of approximately $3 \%$.

\section{Mites}

An infestation with fowl mites (Dermanyssus gallinae) was observed in Trial 1 . The infestation was so heavy that 6 birds died as a result of the mites' blood-sucking activity. In order to reduce the number of mites, the fittings in the hen house (mainly nests and perches) were treated 4 times with metriphonate. The hens, however, were not treated. After the first trial, the hen house was completely sanitised before Trial 2 . Also between the following trials the interior of the hen house was treated with acaricides. In Trials 2-5, mites were not observed.

\section{Serology}

Antibodies against IBDV were demonstrated in birds in trials 4 and 5, both before and after the trial. All other serological analyses were negative. As Swedish layers are not vaccinated against IBD the antibodies indicate an infection with a field virus during rearing. However, no increase in mortality in the laying phase was recorded due to this fact. 
Table 2. Mortality and important findings at autopsy (percentage of dead birds put in relation to the number of living hens at 16 and 20 weeks of age, respectively).

\begin{tabular}{|c|c|c|c|c|c|c|c|}
\hline \multirow{2}{*}{$\begin{array}{l}\text { Trial } \\
\text { Hybrid }\end{array}$} & \multirow{2}{*}{$\begin{array}{c}1 \\
\text { LSL }\end{array}$} & \multirow{2}{*}{$\begin{array}{c}2 \\
\text { LSL }\end{array}$} & \multicolumn{2}{|c|}{3} & \multirow{2}{*}{$\begin{array}{c}4 \\
\mathrm{LSL}\end{array}$} & \multicolumn{2}{|c|}{5} \\
\hline & & & LB & LSL & & SLU-1329 & LSL \\
\hline \multicolumn{8}{|l|}{ Dead from 16-20 weeks } \\
\hline Total mortality & 1.79 & 0.68 & 0.29 & 0.25 & 0.10 & 0.45 & 0.33 \\
\hline Cannibalism & 0.02 & 0.04 & & & & & \\
\hline Hepatitis & 0.11 & & & & & & \\
\hline Emaciation & 1.55 & 0.40 & 0.29 & 0.08 & 0.08 & 0.25 & 0.17 \\
\hline Coccidiosis & & 0.02 & & & & & \\
\hline Lymphoid leucosis & & 0.11 & & & & & \\
\hline Other tumours & & 0.02 & & & & & \\
\hline Fatty liver syndrome & & & & & & 0.04 & \\
\hline \multicolumn{8}{|l|}{ From 20 to 80 weeks } \\
\hline Total mortality & 4.0 & 15.6 & 20.9 & 6.3 & 6.0 & 7.2 & 6.0 \\
\hline Cannibalism & 0.29 & 2.42 & 7.15 & 0.30 & 0.15 & 2.41 & 1.21 \\
\hline Hepatitis & 0.33 & 0.94 & 0.45 & 0.51 & 0.23 & 0.33 & 0.33 \\
\hline Salpingitis & 1.17 & 2.29 & 7.85 & 2.09 & 2.21 & 0.75 & 1.00 \\
\hline Emaciation & 0.20 & 0.28 & 1.17 & 0.17 & 0.32 & 0.25 & 0.08 \\
\hline Coccidiosis & & 3.15 & 0.45 & & & & \\
\hline Lymphoid leucosis & 0.20 & 2.76 & 0.05 & 0.68 & 0.04 & & \\
\hline Other tumours & 0.40 & 0.64 & 0.05 & 0.72 & 0.62 & 0.17 & 0.21 \\
\hline Fatty liver syndrome & 0.24 & 0.21 & 0.15 & 0.09 & 0.11 & 0.29 & 0.21 \\
\hline
\end{tabular}

Live weight and exterior appearance

Mean live weights for LSL in the 5 trials were $1.76,1.65,1.87,1.83$ and $1.75 \mathrm{~kg}$ at 35 weeks, and $1.84,1.67,1.87,1.93$ and $1.90 \mathrm{~kg}$ at 55 weeks. In trial 3, LB-hens were heavier with a weight of $1.93 \mathrm{~kg}$ at 35 weeks and $2.00 \mathrm{~kg}$ $(\mathrm{p}<0.05)$ at 55 weeks. In trial 5, SLU-1329hens were also heavier with a weight of $1.84 \mathrm{~kg}$ $(\mathrm{p}<0.01)$ at 35 weeks and $1.95 \mathrm{~kg}$ at 55 weeks.

The exterior appearance is shown in Figs. 2 and 3. Within the LSL-hybrid the plumage condition varied greatly between the trials, being very poor in Trial 2 . The poorest plumage condition was recorded in the LB hybrid in Trial 3, where many hens were more or less naked. In this trial, LSL had better plumage condition at $55 \mathrm{w}$ than LB on neck $(\mathrm{p}<0.05)$, vent $(\mathrm{p}<0.05)$, back $(p<0.01)$, cloaca $(p<0.001)$ and tail $(p<0.05)$. No significant differences regarding plumage condition were found between LSL and SLU-1329, but both hybrids had very good plumage condition in Trial 5. Cleanliness of plumage was fairly good in all years except for LSL in Trial 3 where the scores were found to be better in LB than in LSL $(p<0.01)$.

The incidence of bumble foot was higher at 35 weeks than at 55 weeks, and at the lower age LSL seemed to be more affected than both LB $(p<0.08)$ and SLU-1329 $(p<0.05)$. The effect of perches covered with rubber in Trials 4 and 5 on bumble foot and keel bone deformation could not be analysed statistically, but the results in this pen did not seem to be very different from the other pens with hardwood perches. Only a couple of less severe cases of toe pad hyperkeratosis were seen. Shorter claws were recorded in LB and SLU-1329 than in LSL $(\mathrm{p}<0.05$ at 35 weeks and $\mathrm{p}<0.01$ at 55 weeks). At $55 \mathrm{w}, \mathrm{LB}$ had significantly better keel bone condition than LSL $(p<0.05)$. Wounds from pecks and 
Fig. 2a

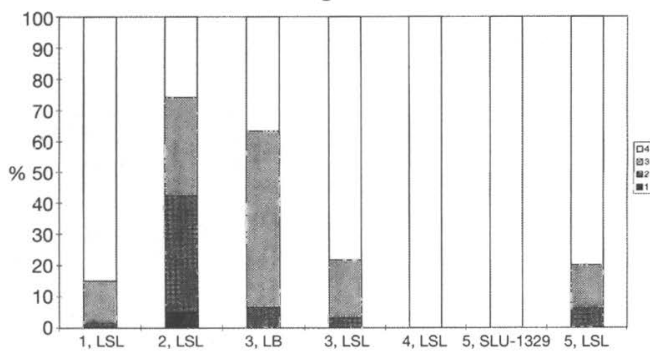

Fig. 2c

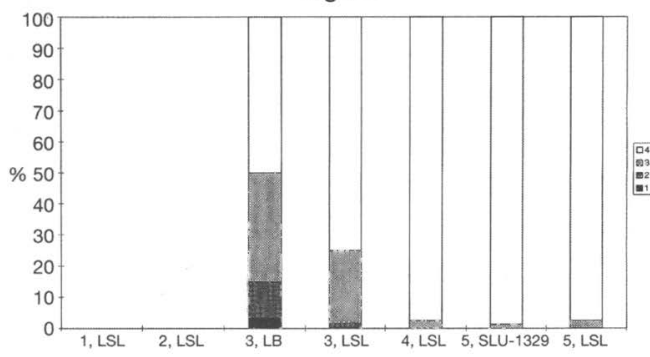

Fig. $2 \mathrm{e}$

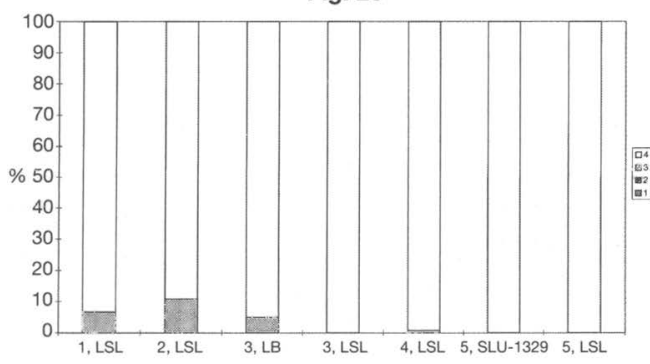

Fig. $2 \mathrm{~g}$

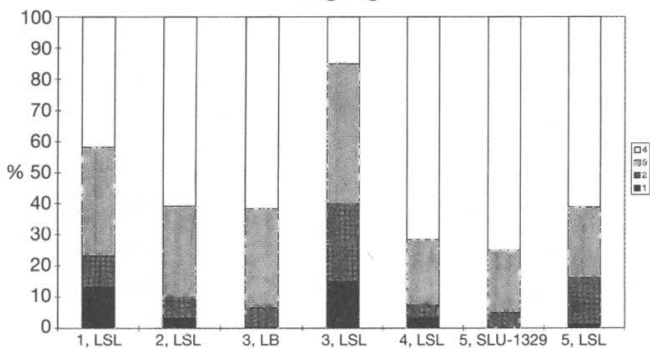

Fig. 2b

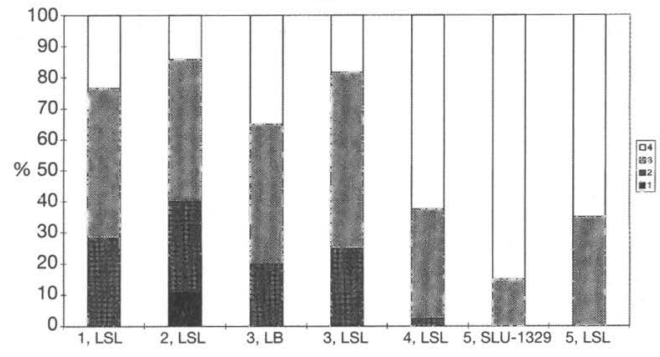

Fig. 2d

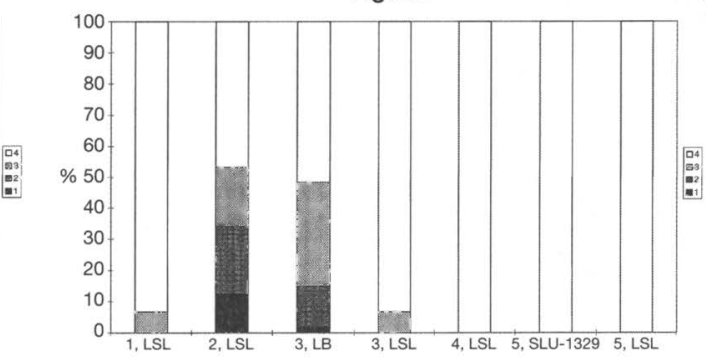

Fig. $2 f$

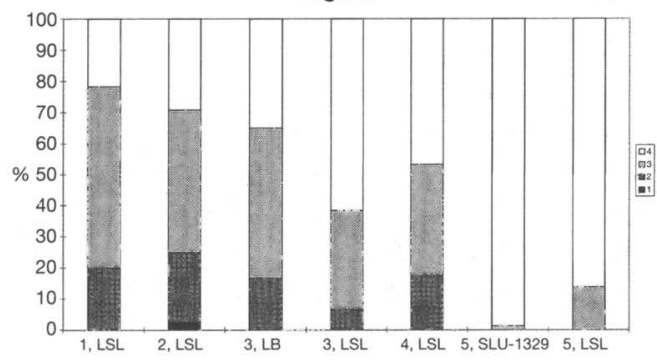

Fig. 2h

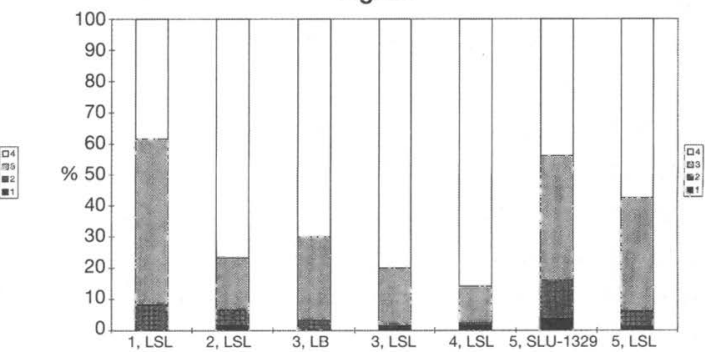

Figure 2. Proportion of birds in 4 categories at scoring of exterior appearance at 35 weeks during the 5 trials. $2 \mathrm{a}$ plumage on neck; $2 \mathrm{~b}$ plumage on vent, $2 \mathrm{c}$ plumage around cloaca, $2 \mathrm{~d}$ plumage on back, $2 \mathrm{e}$ plumage on wings, $2 \mathrm{f}$ plumage on tail, $2 \mathrm{~g}$ bumble foot, $2 \mathrm{~h}$ keel bone condition. White indicates intact body part (score 4 ) and black indicates a very poor condition (score 1 ). 
Fig. 3a

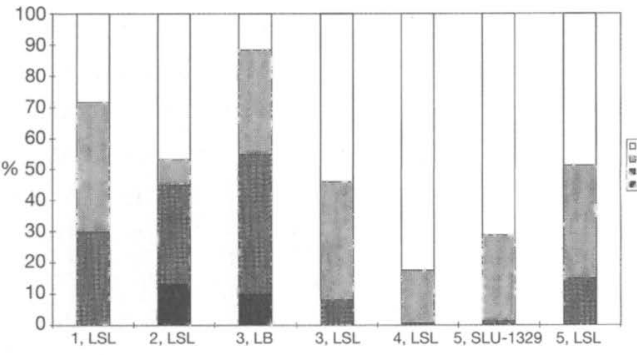

Fig. 3c

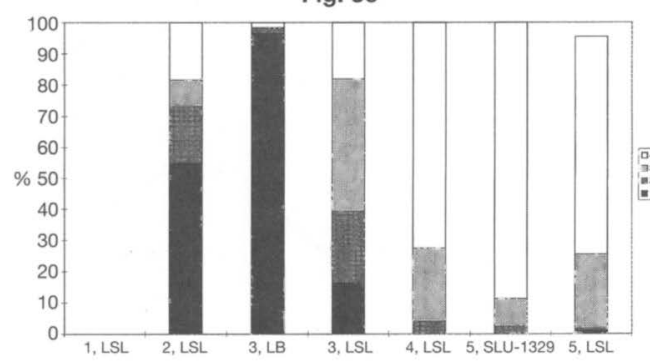

Fig. 3e

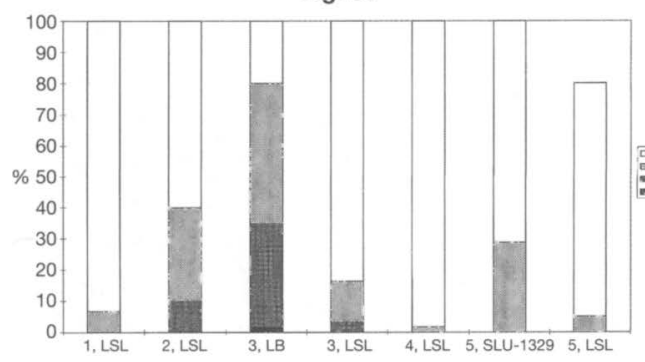

Fig. $3 g$

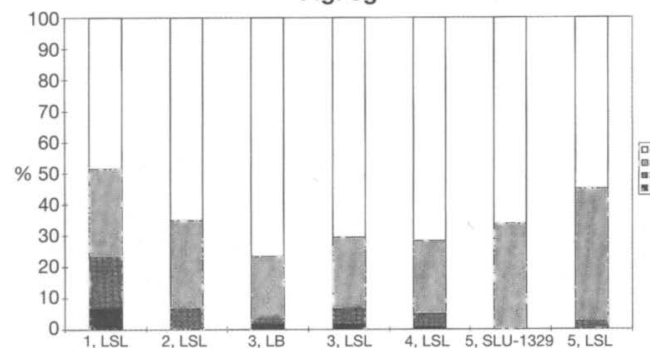

Fig. 3b

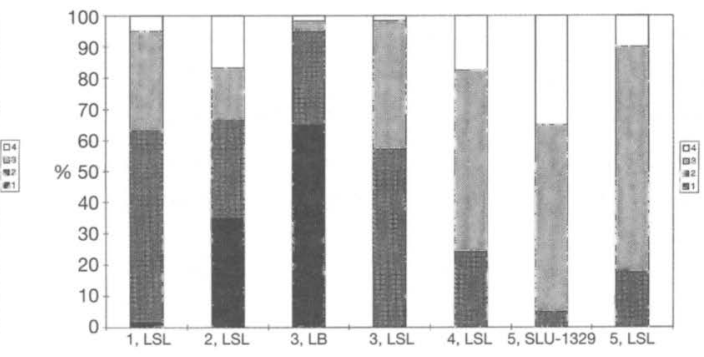

Fig. 3d

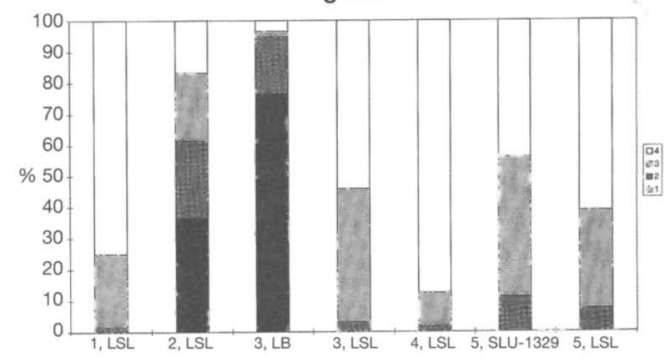

Fig. $3 f$

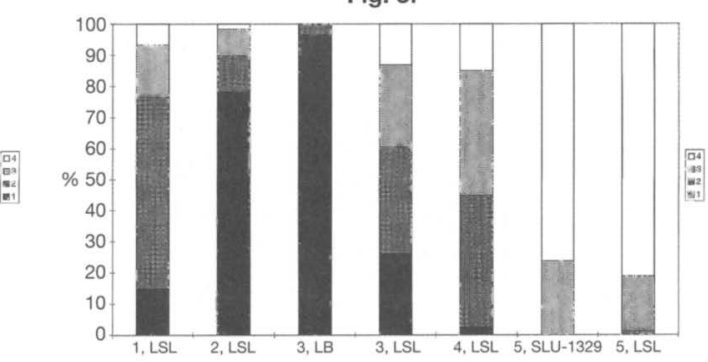

Fig. 3h

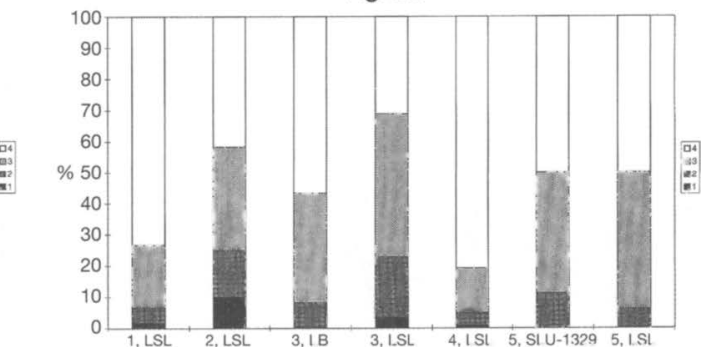

Figure 3. Proportion of birds in 4 categories at scoring of exterior appearance at 55 weeks during the 5 trials. $3 \mathrm{a}$ plumage on neck; $3 \mathrm{~b}$ plumage on vent, $3 \mathrm{c}$ plumage around cloaca, $3 \mathrm{~d}$ plumage on back, $3 \mathrm{e}$ plumage on wings, $3 \mathrm{f}$ plumage on tail, $3 \mathrm{~g}$ bumble foot, $3 \mathrm{~h}$ keel bone condition. White indicates intact body part (score 4 ) and black indicates a very poor condition (score 1 ). 
scratches on the cloaca region were most common in birds with this body part denuded, and LB consequently had more wounds than LSL at 55 weeks $(p<0.05)$. Less than $20 \%$ of the hens had severe pecks on the comb (scores 1 and 2) and no particular differences between the hybrids were recorded.

\section{Discussion}

Since 1991 the Marielund aviary system has entered the Field Phase Testing program at some commercial farms in Sweden carried out under the control of the Swedish Board of Agriculture (Statens Jordbruksverk 1996). Although not studied as closely as in the present investigation, the experiences hitherto are similar to the results reported here, although production levels and mortality rates are slightly better in white light hybrids.

Considerable differences between trials were observed concerning mortality. Higher mortality was recorded for LB than for LSL which agrees with Abrahamsson \& Tauson (1995). Results from other studies with other designs of aviaries in the field also show a higher mortality in flocks with brown hybrids than in white Leghorn (Statens Jordbruksverk 1996). The most important causes of mortality were salpingitis and cannibalism. High frequencies of salpingitis seem to be correlated to high frequencies of cannibalism. Thus, in Trial 3 the frequencies of both salpingitis and cannibalism were very high. Results from other studies on aviaries $(\mathrm{Al}$ gers et al. 1995, Abrahamsson \& Tauson 1995, Abrahamsson et al. 1996b) also indicate that a high incidence of salpingitis often is observed when severe cannibalism occurs in a flock. A high stress level in a flock troubled with cannibalism and a high frequency of vent pecking resulting in wounds and infections at the cloacal orifice may be important predisposing factors. Results from both experimental and field stud- ies (Abrahamsson \& Tauson 1995, Statens Jordbruksverk 1996) show that cannibalism is one of the biggest threats to housing birds in larger groups, e.g. in aviary systems if beak trimming is not performed. On the other hand, as in the present 5 batches of birds, there were considerable variations between different studies reported. The risk of cannibalism could probably be reduced by some adjustments concerning choice of hybrid, rearing and nest design. For the time being it seems wise to choose hybrids known to have a lower risk of cannibalism. Birds that lay eggs on the floor instead of in the nests may run a high risk of being pecked at the cloacal region, which often may lead to gut pulling (Abrahamsson et al 1996b). Different designs or positions of the nests and a different form of rearing may, however, reduce the problem with misplaced eggs.

In Sweden, in contrast to most other countries where beak-trimming is allowed in order to prevent cannibalism, one of the few means to try to reduce this malbehaviour in a flock is to reduce light. However, this may have other consequences, e.g. like increasing the number of misplaced eggs as well decreasing the working environment for people working in the house.

Appearance of parasitic disorders and medication in the cases of Red mite invasion in Trial 1 or coccidiosis in Trial 2 agree with similar situations in Dutch aviary housing on a commercial scale as reported by Blokhuis \& Metz (1996) and van Horne (1997). The considerable level of unpredictability, where good results are mixed with unacceptable ones, agrees with Meierhans et al. (1992).

For chickens housed in litter-based systems, coccidiosis is a constant threat. In Trials 1-3, the chicks were given anticoccidials via feed, whereas no anticoccidials were given to chicks reared for Trials 4 and 5 in order to get a better immunisation in the latter. The outbreak of coccidiosis during rearing of chicks destined for 
Trial 5 was probably a consequence of the absence of preventive medication. Immunosuppression caused by early infection with IBDV might have been a contributory factor. However, no signs of coccidiosis were observed during the laying period in Trials 4 and 5.

The ideal preventive measure against coccidiosis is controlled immunisation of the chicks during the rearing period. Since 1995 a live coccidial vaccine has been available in Sweden which, once found efficiency has been proved, would allow a safer way of immunisation.

In Trial 2, mortality caused by lymphoid leucosis (LL) reached $2.7 \%$. The occurrence of $L L$, however, is not influenced by the choice of housing system for the adult layers as there is practically no horizontal transmission in chicks older than 3-4 weeks (Purchase 1987). The lower live weight of the birds in Trial 2 might also have been influenced by poor plumage condition, since the hens need extensive extra energy intake to compensate for losses of heat due to poor feather coverage (Tauson \& Svensson 1980). A combination effect of weak birds, low-ranked birds and competition around the feeders in a large flock of hens might also have occurred.

In Trial 1, some of the birds were unable to find feed and water during the first weeks after being transferred to the layer house, which led to increased mortality. The cause of this problem was probably the rearing, where the pullets had water and food in troughs placed on the litter floor. In the other trials, the pullets had water and food on raised manure bins covered with welded wire, and had then learnt to move vertically to a greater extent and eat from wire platforms. Another factor that might have contributed was that in the later trials, when initially housing the birds, the staff tried to put all of them on the feeding tiers, with only few placed on the resting tier or on the litter bed. The modification of the light programme within the aviary in order to direct birds towards feed in the morning and the resting tier before dusk probably also facilitated the finding of food and water, as well as other facilities (Tanaka \& Hurnik 1991).

Feather pecking was most severe in LB, which is in accordance with Abrahamsson \& Tauson (1995). The good plumage condition of SLU1329 is in agreement with results of Karlsson et al. (1997). This hybrid has also shown good plumage condition in traditional low-density systems (Wilhelmsson et al. 1996, Wilhelmsson \& Carlgren 1996). Hence, by choosing hybrids that have shown good plumage in aviaries, the risk of feather pecking may probably be reduced. The difference between LB and LSL concerning cleanliness of plumage is likely to be due to the fact that soiled feathers are much harder to detect in brown birds than in white, but might also have been caused by a large proportion of the LB hens being more or less naked.

The occurrence of bumble foot and keel bone deformation agrees with experimental studies (Siegwart 1991, Tauson \& Abrahamsson 1994) as well as reports from the field (Statens Jordbruksverk 1996). These lesions often occur if the hens have access to perches. Incidence and severity are influenced by perch design and by hybrid (Oester 1994, Tauson \& Abrahamsson 1996). The lack of obvious effects of the rubber-covered perches in Trials 4 and 5 agrees with Tauson \& Abrahamsson (1996). The very low proportion of toe pad hyperkeratosis found agrees well with Tauson \& Abrahamsson (1994) who reported that this toe pad defect appears almost only in conventional cages.

\section{Conclusion}

The overall impression of this study is that health, especially as regards mortality, in birds kept in an aviary like Marielund may be quite 
acceptable when the system works well. The risk of parasites, cannibalism, foot abscesses, keel bone lesions and spreading within the whole flock of feather pecking is, however, still high. The results of the present study, as well as of other experimental studies, indicate that for some traits certain measures can be taken in order to reduce the problems and hence, reduce unpredictability between batches of birds.

\section{Acknowledgements}

The study was sponsored by Svenska Djurskyddsföreningen, Lantbruksstyrelsen, Stiftelsen Veterinär Fjäderfäforskning, Sveriges Allmänna Djurskyddsförening and Kalmar Djurskyddsförening. AB Bröderna Victorsson is thanked for providing the aviary and carrying out its modifications. The Poultry Division at Department of Animal Breeding and Genetics is thanked for providing the day-old chicks for the rearing of SLU-1329 pullets in Trial 5. All the technical staff at the Avian Division at the Department of Animal Nutrition and Management, and particularly Mrs Eva Jerpdal, are thanked for excellently taking care of the birds at the Marielund poultry house.

\section{References}

Abrahamsson P, Tauson R:. Aviary systems and conventional cages for laying hens - Effects on production, egg quality, health and bird location in 3 hybrids. Acta Agric. Scand., Section A, Animal Sci. 1995, 45, 191-203.

Abrahamsson P, Tauson R: Performance and egg quality of laying hens in an aviary system over 5 batches of birds. J. of Applied Poultry Res. 1998, in press.

Abrahamsson P, Tauson R, Appleby MC: Behaviour, health and integument of 4 hybrids of laying hens in modified and conventional cages. Br. Poultry Sci. 1996a, 37, 521-540.

Abrahamsson P, Tauson R, Elwinger $K$ : Effects on production, health and egg quality of varying proportions of wheat and barley in diets for two hybrids of laying hens kept in different housing systems. Acta Agric. Scand., Section A, Animal Sci. 1996b, 46, 173-182.

Algers B, Ekstrand C, Geismar J, Gunnarsson S, Odén $K$, Onila $M$, Svedberg $J$ : Utvärdering av
Oli-Voletage inhysningssystem för värphöns. (Evaluation of the Oli-Voletage system for laying hens). Specialarbete 31 . Swedish University of Agricultural Sciences. 1995.

Appleby MC: Should cages for laying hens be banned or modified? Animal Welfare 1993, 2, 27-80.

Blokhuis HJ, Metz JHM: Integration of animal welfare into housing systems for laying hens. Neth. J. Agric. Sci. 1992, 40, 327-337.

Blokhuis HJ, Metz JHM: Aviary housing for laying hens. Editors Blokhuis HJ and Metz JHM. IMAG-DLO, Wageningen, the Netherlands. 1996.

Gregory NG, Wilkins LJ: Broken bones in domestic fowl: Handling and processing damage in end-oflay battery hens. Br. Poultry Sci. 1989, 30, 555562.

Hansen I: Ethological studies of laying hens in aviaries and cages. Thesis, Dept. of Anim. Sci., Agricultural University of Norway. 1993. 80 pages.

Karlsson A, Elwinger K, Tauson R: Production, egg quality and plumage condition of hens in an aviary system fed diets with varying oats/wheat ratios. Proc. 11 th European Symposium on Poultry Nutrition. Faaborg, Denmark. 1997. pp. 416418.

Keeling $L J$ : Feather pecking - who in the group does it, how often and under what circumstances? Proc. 9th European Poultry Conference, Glasgow 7-12 August 1994, WPSA, Vol 1. 1994. pp. 288289.

Kathle J, Kolstad N: Non-beaked laying hens housed in aviaries. I: Production performance in cages and three types of aviaries. NJAS 1996, 10 (4), 413-424.

Meierhans D, Amgarten M, Guler HP, Strasser M: The economical consequences of the introduction of alternative housing systems for laying hens in Switzerland. XIX World Poultry Science Congress, Amsterdam. Poster Session 24. Swiss Poultry Husbandry School, Burgerweg 22, 3052 Zollikofen, Switzerland. 1992. pp. 8.

Oester H: Sitzstangenformen und ihr Einfluss auf die Entstehung von Fussballengeschwüren bei Legehennen. (Different types of perches and their influence of the development of bumble feet in laying hens). Arch. Geflügelk. 1994, 58, 231-238.

Purchase HG: The pathogenesis and pathology of neoplasms caused by avian leucosis viruses. In; de Boer G F (ed) Avian Leucosis, Martinus Nijhoff, Boston. 1987. pp 171-196. 
SAS Institute Inc: SAS/STAT * User's Guide, Version 6, fourth Edition, Volume 2, 1989, 846 pp. (Cary, N.C., USA).

Siegwart N: Ursache und Pathogenese von Fussballengeschwüren bei Legehennen. (Cause and paathogenesis of bumble foot in laying hens). Dissertation. Inst. für Tierpathologie. Universität Bern. 1991. 143 pp.

Simonsen HB, Vestergaard $K$, Willeberg $P$ : Effect of floor type and density on the integument of egglayers. Poultry Sci. 1980, 59, 2202-2206.

Statens Jordbruksverk: Värphöns kontrollstation 1996. Report 1996:6. Swedish Board of Agriculture, 55182 Jönköping, Sweden. 1996.

Snedecor GW, Cochran WG: Statistical Methods, 6th ed. The Iowa State Univ. Press, Ames, Iowa, 1968, 593 pp.

Svedberg J: The connection between environment and foot conditions in laying hens. Environment and animal health Proc. 6th Int. Congress on Animal Hygiene, Skara, 1988. pp. 125-130.

Tanaka T, Hurnik JF: Behavioral responses of hens to simulated dawn and dusk periods. Poultry Sci. 1991, 70, 483-488.

Tauson R: Cages: How can they be improved? In: Moss, R. (ed.): The laying hen and its environment. Martinus Nijhoff, The Hague, 1980. pp. 269-304.

Tauson R: Mortality in laying hens caused by differences in cage design. Acta Agric Scand. 1985, $35,165-174$.

Tauson R, Abrahamsson P: Foot and skeletal disorders in laying hens. Effects of perch design, hybrid, housing system and stocking density. Acta Agric. Scand., Sect. A, Animal Sci. 1994, 44, 110-119.

Tauson R, Abrahamsson P: Foot and keel bone disorders in laying hens. Effects of artificial perch material and hybrid. Acta Agric. Scand., Section A, Animal Sci. 1996, 4, 239-246.

Tauson R, Ambrosen T, Elwinger K: Evaluation of procedures for scoring the integument of laying hens.-Independent scoring of plumage condition. Acta Agric. Scand. 1984, 34, 400-408.

Tauson R, Jansson L, Abrahamsson P: Studies on alternative keeping systems for laying hens in Sweden at the Dept. of Animal Nutrition and Management, Swedish University of Agricultural Sciences, Uppsala. Report 209. 1992. 32 pp.

Tauson R, Svensson SA: Influence of plumage condition on the hen's feed requirement. Swedish J. agric. Res. 1980, 10, 35-39.
Taylor AA, Hurnik JF: The effect of long-term housing in an aviary and battery cages on the physical condition of laying hens: Body weight, feather condition, claw length, foot lesions, and tibia strength. Poultry Sci. 1994, 73, 268-273.

van Horne PLM: Production, animal health and economic results of commercial layer flocks in aviary systems. In: Koene P, Blokhuis HJ (eds.): Proc. of 5th European Symposium on Poultry Welfare, Posen and Looyen, Wageningen. The Netherlands., 1997. pp. 125-126.

Wilhelmsson $M$, Carlgren $A-B$ : Djurmaterial i den framtida äggproduktionen - en jämförelse mellan en universitetskorsning och en kommersiell hybrid (Laying stock for the future - a comparison between an experimental cross and a commercial hybrid). Report 127. Dept. of Animal Breeding and Genetics, Swedish University of Agricultural Sciences, Uppsala, Sweden.(In Swedish) 1996. 14 pages.

Wilhelmsson $M$, Carlgren A-B, Tauson R: Djurmaterial i den framtida äggproduktionen - en jämförelse mellan fyra hybrider (Laying stock for the future - a comparison between 4 commercial hybrids). Report 126. Dept. of Animal Breeding and Genetics, Swedish University of Agricultural Sciences, Uppsala, Sweden. (In Swedish) 1996. 13 pages.

\section{Sammanfattning}

Hälsa hos värphöns $i$ ett våningssystem under fem produktionsomgångar.

Mortalitet och hälsa studerades hos värphöns under 5 djuromgångar i praktisk skala, med ca 4700 höns per djuromgång. Inhysningssystemet var Marielund, ett 3-vånings aviärsystem för hög beläggning (i detta fall ca 17 höns per $\mathrm{m}^{2}$ stallgolvyta) med ströbädd. De 3 värphönshybriderna som användes var Lohmann Selected Leghorn (LSL) i alla 5 omgångarna, Lohmann Brown (LB) i omgång 3 och den s.k. svenskhönan som utvecklats vid Inst. för husdjursgenetik, SLU (SLU-1329) i omgång 5. Hönsen var inte näbbtrimmade. All skötsel och insamling av rådata sköttes av personal från Institutionen för husdjurens utfodring och vård, SLU, Uppsala.

Dödligheten varierade mellan boxar och omgångar från 3,4 till 7,8\%, utom bland LSL i omgång 2 och LB i omgång 3 där den var betydligt högre $(15,6$ respektive $20,9 \%$ av antal insatta). De vanligaste ob- 
duktionsfynden var salpingit (äggledarinflammation) och kannibalism. Coccidios och lymfoid leukos bidrog i väsentlig grad till den höga dödligheten $i$ omgång 2.

Fjäderplockning förekom i varierande grad hos LSLhönsen, men värst drabbad var LB där en stor andel av hönsen var näst intill helt nakna. SLU-1329 var inte särskilt hårt drabbad av fjäderplockning. Fotbölder var vanligare vid 35 veckors ålder än vid 55 .
LSL var värre drabbad av denna skada än LB och SLU-1329.

Sammanfattningsvis visar studien att hälsan hos höns i aviärsystem kan vara fullt acceptabel. Risken för parasiter, kannibalism, fot- och bröstbensskador samt fjäderplockning är dock fortfarande för hög. Mycket tyder dock på att flera av dessa problem i framtiden kommer att kunna minskas.

(Received September 2, 1997; accepted May 3, 1998).

Reprints may be obtained from: R. Tauson, Swedish University of Agricultural Sciences, S-755 97 Uppsala, Sweden. E-mail: ragnar.tauson@huv.slu.se, tel: +46 018-674500, fax: +46 018-674501. 
